\title{
Correction to: Advances in Swarm Intelligence
}

\author{
Ying Tan (1), Yuhui Shi, and Milan Tuba
}

\section{Correction to: \\ Y. Tan et al. (Eds.): Advances in Swarm Intelligence, LNCS 12145, https://doi.org/10.1007/978-3-030-53956-6}

In the version of the paper 60 that was originally published the affiliation of Jairo R. Coronado and Alfonso Romero has been changed from "Universidad de la Costa" to "Researcher" because this paper was made within the framework of a project of the Colombian Navy.

Further the following acknowledgments has been placed at end of the paper: The work described in this paper has been supported by the project "PLANEAMIENTO POR CAPACIDADES PARA EL ESTABLECIMIENTO DE UNA BASE TEMPORAL EN LA ANTÁRTICA COMO SOPORTE LOGÍSTICO A LAS OPERACIONES CIENTÍFICAS - 65028" under the auspices of the Armada Nacional de Colombia and Ministry of Science, Technology and Innovation (MinCiencias).

The original version of the chapter 27 was revised. The author name "Yingshi Tan" is updated to "Yingsi Tan".

The updated version of these chapters can be found at 